\title{
EFEK INTERAKSI LITERASI KEUANGAN DALAM KEPUTUSAN INVESTASI: PENGUJIAN BIAS-BIAS PSIKOLOGI
}

\author{
Wendy ${ }^{1}$ \\ Universitas Tanjungpura, Indonesia
}

\begin{abstract}
This research aims to analyze psychological biases that occur when investors make risky investment decisions. There are five behavioral factors analyzed (herding, overconfidence, disposition effect, conservatism, and availability). Financial literacy is used as moderator in analyzing the effect of those bahaviors towards risky investment decisions. This research examines four econometric equations in explaining financial literacy as a moderator. Interaction effect testing is carried out using moderating variable regression. The results show that psychological biases occur in making risky investment decisions. Herding behavior, overconfidence, disposition effect, and conservatism show a positive effect, while availability does not show a significant effect. Testing on the interaction model finds that financial literacy is able to reduce these psychological biases. This finding also explains the managerial implications that investors with high levels of financial literacy have the potential to experience relatively low psychological biases compared to investors with limited levels of financial literacy. In terms of limitations, this research uses a questionnaire survey that has not been able to reveal aspects of investor behavior in a comprehensive manner. In addition, the number of respondents who are more dominated by beginner investors also adds to the limitations in carrying out the generalization.
\end{abstract}

JEL : G32, G34

Keywords : psychological biases, behavioral finance, investment decisions, financial literacy, interaction effects.

\begin{abstract}
ABSTRAK
Riset ini bertujuan untuk menganalisis bias-bias psikologi yang terjadi ketika pemodal mengambil keputusan investasi berisiko. Terdapat lima faktor perilaku yang dianalisis, yaitu perilaku herding, overconfidence, disposition effect, conservatism, dan availability. Literasi keuangan digunakan sebagai pemoderasi dalam menganalisis pengaruh faktor-faktor keperilakuan tersebut terhadap keputusan investasi berisiko. Riset ini menguji empat persamaan ekonometrika dalam menjelaskan peran literasi keuangan sebagai pemoderasi. Pengujian efek interaksi dilakukan dengan menggunakan regresi variabel moderasi. Hasil analisis menunjukkan bahwa bias-bias psikologi terjadi dalam pengambilan keputusan investasi berisiko. Perilaku herding, overconfidence, disposition effect, dan conservatism menunjukkan pengaruh positif terhadap pengambilan keputusan investasi berisiko, sementara bias availability tidak menunjukkan pengaruh yang bermakna dalam riset ini. Pengujian pada model interaksi menemukan bahwa literasi keuangan mampu mereduksi bias-bias psikologi tersebut. Temuan ini sekaligus menjelaskan implikasi manajerial bahwa pemodal dengan tingkat literasi keuangan yang baik berpotensi mengalami bias-bias psikologi yang relatif lebih rendah dibandingkan pemodal dengan tingkat lietrasi keuangan yang terbatas. Dari sisi keterbatasan, riset ini menggunakan survei kuesioner yang belum mampu mengungkap aspek perilaku pemodal secara komprehensif. Selain itu, jumlah responden yang lebih didominasi oleh pemodal pemula juga menambah keterbatasan dalam melakukan generalisasi hasil penelitian.
\end{abstract}

Kata Kunci : bias psikologi, keuangan keperilakuan, keputusan investasi, literasi keuangan, efek interaksi.

${ }^{1}$ Email : wendy@ekonomi.untan.ac.id

Received : 29-11-2020, Accepted: 19-04-2021, Published: 29-04-2021

P-ISSN : 2087-9954, E-ISSN : 2550-0066. DOI : http://dx.doi.org/10.26418/jebik.v10i1.43403 


\section{PENDAHULUAN}

Teori pengambilan keputusan telah mengalami evolusi yang panjang dalam beberapa puluh tahun terakhir. Asumsi rasionalitas (expected utility theory) yang selama ini digunakan dalam menjelaskan teori pengambilan keputusan mulai dikritisi. Beberapa penelitian empiris menunjukkan bahwa agen ekonomi tidak hanya menggunakan rasionalitasnya dalam mengambil keputusan, tetapi juga dipengaruhi oleh faktor keperilakuan (Tversky \& Kahneman, 1992; Gill, Khurshid, Mahmood, \& Ali, 2018; Cartwright, 2018). Temuan tersebut menunjukkan bahwa agenagen ekonomi dapat memberikan respon emosional ketika mengambil keputusan investasi sehingga berpotensi menimbulkan sejumlah bias psikologi yang mengarah pada perilaku irasional.

Istilah perilaku rasional dan irasional dalam ranah ilmu keuangan dapat dijelaskan sebagai berikut. Ketika agen ekonomi mengambil keputusan investasi yang didasarkan pada hukumhukum keuangan positif dengan mengedepankan analisis kuantitatif secara komprehensif dan simulasi-simulasi berdasar pohon keputusan untuk memilih keputusan terbaik (utilitas tertinggi), maka agen ekonomi tersebut dapat dikatakan rasional. Sebaliknya, apabila perasaan dan emosi yang dikedepankan dalam mengambil keputusan investasi, maka hasil keputusan cenderung mengarah pada perilaku irasional akibat pengaruh bias-bias psikologi (herding, overconfidence, disposition effect, conservatism, hingga availability). Argumentasi ini sejalan dengan hasil penelitian Bakar \& Yi (2016) yang menunjukkan bahwa keputusan investasi dapat dipengaruhi oleh berbagai bias psikologi.

Menurut Ouarda, El Bouri, \& Bernard (2013) perilaku herding dapat diartikan sebagai perilaku meniru atau mengimitasi keputusan orang lain, yang sering digunakan sebagai jalan pintas oleh individu. Sementara itu, overconfidence merupakan suatu kondisi di mana pemodal menilai terlalu tinggi kemampuan mereka dan berfikir memiliki informasi yang lebih baik dibandingkan pemodal lain (Qadri \& Shabbir, 2014). Secara umum, perilaku overconfidence dapat dijelaskan sebagai kecenderungan mengambil keputusan tanpa disadari, yang memberikan bobot penilaian berlebih pada pengetahuan dan akurasi informasi yang dimiliki dengan mengabaikan informasi publik yang tersedia. Uraian tersebut secara implisit menjelaskan adanya pengaruh perilaku herding dan overconfidence terhadap keputusan investasi para agen ekonomi.

Rau (2014) menjelaskan disposition effect sebagai kecenderungan para pemodal untuk menjual lebih cepat saham berkinerja baik (winner) dan menahan terlalu lama saham berkinerja buruk (losser). Fenomena ini pada prinsipnya akan merugikan pemodal sendiri, di mana saham winner yang dijual terus berkinerja baik, sementara saham losser yang ditahan terus memburuk kinerjanya. Kondisi ini sering dialami pemodal di bursa saham. Agen ekonomi yang mengalami bias disposisi cenderung akan mengambil keputusan investasi yang tidak optimal akibat dikesampingkannya aspek rasionalitas.

De Bondt \& Thaler (1985) dan Moradi, Mostafaei, \& Meshki (2013) menjelaskan conservatism sebagai suatu proses mental yang terjadi pada individu, di mana individu lebih memercayai prediksi sebelumnya (prior views) dibandingkan informasi saat ini. Di samping itu, terdapat tendensi individu merasa lebih terbebani untuk mengakui informasi baru yang bertentangan dengan analisisnya. Sebagai contoh, seorang pemodal menerima informasi buruk mengenai saham yang sudah dibeli. Berita baru ini kontradiktif dengan apa yang diprediksi bulan lalu mengenai saham tersebut sehingga membuatnya sulit menerima kenyataan. Dengan demikian, 
agen ekonomi yang terpengaruh bias konservatisme cenderung akan membuat keputusan investasi yang tidak optimal.

Santa-Clara \& Valkanov (2003) serta Sachan \& Chugan (2020) menjelaskan availability sebagai rule of thumb yang memungkinkan individu untuk mengestimasi probabilitas suatu outcome berdasar pada seberapa umum dan dekat outcome tersebut terjadi. Individu akan mengalami bias availability ketika cenderung memersepsikan probabilitas-probabilitas yang lebih mudah diingat dibandingkan prospek-prospek yang sulit dibayangkan. Ketika agen ekonomi cenderung mengambil keputusan investasi menggunakan informasi dan probabilitas yang lebih mudah dipahami sehingga mengabaikan untuk mencari informasi dan menganalisis prospekprospek lain (yang mungkin lebih sulit diperoleh), maka bias availibilty berpotensi terjadi.

Al-Tamimi (2009) meneliti proses pengambilan keputusan para pemodal di Uni Emirat Arab. Hasil penelitiannya menunjukkan literasi keuangan berpengaruh terhadap keputusan investasi. Sementara itu, penelitian Khalid, Javed, \& Shahzad (2018) menunjukkan bahwa literasi keuangan mampu mengurangi bias psikologi dalam pengambilan keputusan investasi berisiko. Berdasar temuan ini, dapat diduga bahwa agen ekonomi dengan literasi keuangan yang tinggi berpotensi mengalami bias psikologi yang relatif lebih rendah ketika mengambil keputusan investasi, demikian sebaliknya. Aspek rasionalitas juga diduga lebih mendominasi proses pengambilan keputusan investasi pada kondisi literasi keuangan yang baik. Hal ini memperkuat motivasi penulis untuk meneliti lebih jauh keterkaitan literasi keuangan dengan keputusan investasi yang dipengaruhi oleh berbagai bias psikologi.

Meskipun penelitian-penelitian terdahulu menunjukkan keputusan investasi dapat dipengaruhi oleh berbagai bias psikologi (Khalid et al., 2018; Bakar \& Yi, 2016), namun belum ditemukan kajian komprehensif yang membahas mengapa para agen ekonomi memiliki derajat bias psikologi yang berbeda ketika mengambil keputusan investasi. Kenyataan ini memunculkan pertanyaan riset mengenai "mengapa bias psikologi memiliki pengaruh yang berbeda di antara para agen ekonomi?" Ada yang pengaruhnya kuat, sementara yang lain pengaruhnya lebih lemah. Oleh karena itu, diperlukan sebuah rerangka konseptual yang idealnya mampu memberi penjelasan komprehensif mengenai "mengapa" dampak bias-bias psikologi dapat berbeda antar agen ekonomi dalam mengambil keputusan investasi meskipun faktor perilakunya sama.

Riset ini berfokus pada upaya untuk menjawab fenomena tersebut dengan mengambil sudut pandang dari perspektif teori keuangan keperilakuan. Penulis memosisikan variabel literasi keuangan sebagai pemoderasi dalam mengungkap mengapa para agen ekonomi dapat mengalami bias psikologi yang berbeda ketika mengambil keputusan investasi. Penulis melibatkan lima variabel keperilakuan dalam menguji efek interaksi literasi keuangan. Berbagai literatur keuangan keperilakuan menunjukkan bahwa kelima variabel tersebut (herding, overconfidence, disposition effect, conservatism, dan availability) cenderung dialami agen ekonomi saat mengambil keputusan investasi berisiko (Khalid et al., 2018; Bakar \& Yi, 2016).

Penelitian ini juga melibatkan dua variabel kontrol (jenis kelamin dan status pernikahan) untuk mengurangi bias pengukuran dan analisis. Penelitian yang mengintegrasikan berbagai bias psikologi dengan literasi keuangan dan mengontrol sejumlah variabel keperilakuan untuk menjelaskan proses pengambilan keputusan investasi antar agen ekonomi sepengetahuan penulis masih belum ada. Perbedaan-perbedaan tersebut menjadi kebaruan dalam riset ini yang diharapkan 
mampu memberi kontribusi keilmuan yang lebih berwarna dalam riset keperilakuan keuangan di Indonesia.

\section{KAJIAN LITERATUR}

\subsection{Keuangan Keprilakuan}

Teori keuangan standar yang berbasis pada expected utility theory secara umum mengasumsikan pemodal selalu berperilaku rasional (rational agents). Para pemodal dianggap mampu memaksimumkan utilitasnya serta dapat memroses setiap informasi yang tersedia sehingga cenderung mengabaikan faktor psikologi. Kenyataan ini kemudian mendorong berkembangnya teori keuangan keperilakuan (behavioral finance) yang mencoba menganalisis bias psikologi yang tidak dijelaskan dalam teori keuangan standar.

Argumentasi teoritis yang secara implisit mengritisi penggunaan expected utility theory sebagai arus utama dalam menjelaskan proses pengambilan keputusan individual dikemukakan oleh Tversky \& Kahneman (1992) melalui teori prospeknya. Teori ini menjelaskan adanya pemberian bobot (weight) yang berbeda antara keuntungan (gains) dan kerugian (losses) di mata individu. Dalam ukuran absolut yang sama (antara keuntungan dan kerugian), sensitivitas seseorang terhadap kerugian dikatakan sekitar dua kali lipat dibandingkan sensitivitas terhadap keuntungan. Teori prospek dalam perkembangan selanjutnya banyak menginsiprasi riset-riset keuangan keperilakuan di dekade-dekade berikutnya.

Teori keuangan standar dan teori keuangan keperilakuan dalam perkembangannya berjalan secara terpisah, meskipun keduanya memiliki tujuan yang sama dalam memahami fenomena pasar yang kompleks. Banyaknya peneliti yang terlibat dalam riset-riset keuangan keperilakuan menjadikan perspektif baru ini berkembang dengan cepat. Sampai saat ini, kedua perspektif ini mendominasi berbagai riset keuangan di dunia.

\subsection{Literasi Keuangan}

Literasi keuangan menjelaskan kemampuan individu dalam memahami bagaimana proses uang bekerja, bagaimana mengelola dan menghasilkan uang, mengambil keputusan investasi, serta bagaimana individu mendonasikan uangnya untuk membantu orang lain (Giesler \& Veresiu, 2014). Konteks ini mencakup kemampuan seseorang untuk membuat pilihan keputusan pada pengelolaan keuangan, mendiskusikan keuangan dan merencanakan keuangan masa depan, termasuk merespon secara kompeten aktivitas ekonomi yang memengaruhi keputusan pengelolaan keuangan sehari-hari.

Lusardi \& Mitchell (2013) menjelaskan literasi keuangan sebagai kemampuan seseorang dalam memroses berbagai informasi keuangan dan mengambil keputusan berdasar informasiinformasi tersebut. Literasi keuangan yang baik akan mendorong agen ekonomi lebih mampu menilai dan mengelola keuangan serta mengambil keputusan yang lebih rasional. Literasi keuangan mencakup dimensi pengetahuan (knowledge), keyakinan (confidence), dan keterampilan (skill) individu (OJK, 2016).

Chen \& Volpe (1998) menjelaskan empat indikator dalam pengukuran literasi keuangan. Keempat indikator tersebut adalah general knowledge, saving and borrowing, insurance, dan investment. Sementara itu, Atkinson \& Messy (2013) menyebutkan bahwa literasi keuangan merupakan kombinasi dari lima dimensi keperilakuan, yaitu kesadaran (awareness), pengetahuan 
(knowledge), keahlian (skill), sikap (attitude), dan perilaku (behaviours) yang sangat penting bagi individu dalam membuat keputusan keuangan yang baik, sehingga dapat mencapai kesejahteraan. Kelima dimensi tersebut dapat dielaborasi lebih jauh dalam penjelasan berikut.

Kesadaran keuangan merupakan kepercayaan individu terhadap lembaga keuangan formal, kepercayaan dalam menggunakan produk dan jasa keuangan, serta kepercayaan dalam mengelola keuangannya. Pengetahuan keuangan merupakan tingkat pemahaman individu mengenai lembaga keuangan formal, produk, dan layanan keuangannya (termasuk risiko, manfaat, serta hak dan kewajiban). Keahlian keuangan merupakan kemampuan individu dalam melakukan penghitungan sederhana, termasuk menghitung tingkat pengembalian dan produk layanan keuangan serta bunganya. Sementara itu, sikap keuangan mencakup sikap seseorang dalam membuat rencana keuangannya. Terakhir, perilaku keuangan menjelaskan perilaku individu yang berhubungan dengan tujuan menggunakan produk dan layanan jasa keuangan.

\subsection{Herding dan Keputusan Investasi}

Perilaku herding dapat diartikan sebagai perilaku meniru atau mengimitasi keputusan orang lain, yang sering digunakan sebagai jalan pintas oleh individu (Ouarda et al., 2013). Dalam perspektif irasional, perilaku herding dapat diibaratkan sebagai orang buta mengikuti orang buta. Perilaku ini terbentuk sebagai perilaku massal dari interaksi antar individu yang berpikir dan berperilaku sama. Dalam konteks pasar modal, herding muncul ketika pemodal memutuskan untuk mengikuti keputusan pemodal lain atau pergerakan pasar dibandingkan mengikuti keyakinan dan informasi yang dimilikinya (Lakshman, Basu, \& Vaidyanathan, 2013; Yao, Ma, \& He, 2014; Filip, Pochea, \& Pece, 2015).

Perilaku herding dalam keputusan investasi menggambarkan bagaimana individu dalam suatu kelompok dapat bertindak secara kolektif. Herding sendiri mengacu pada situasi di mana individu-individu yang rasional mulai berperilaku irasional untuk meniru orang lain ketika mengambil keputusan. Khairunizam \& Isbanah (2019) dan Addinpujoartanto \& Darmawan (2020) menemukan bahwa herding berpengaruh positif terhadap pengambilan keputusan investasi. Temuan ini sejalan penelitian Hayat \& Anwar (2016) yang menyatakan bahwa herding berpengaruh signifikan terhadap pengambilan keputusan investasi. Uraian tersebut memperkuat argumentasi penulis dalam merumuskan hipotesis pertama.

$\mathrm{H}_{1}$ : Perilaku herding berpengaruh positif terhadap pengambilan keputusan investasi berisiko.

\subsection{Overconfidence dan Keputusan Investasi}

Qadri \& Shabbir (2014) menjelaskan perilaku overconfidence sebagai suatu kondisi di mana pemodal menilai terlalu tinggi kemampuan mereka. Konsep ini diawali dari eksperimen psikologi kognitif terhadap kemampuan memrediksi sesuatu dalam ranah ilmu psikologi. Ketika diaplikasikan dalam riset keuangan, ternyata perilaku ini juga dialami pemodal ketika mengambil keputusan investasi. Beberapa ahli mengartikan perilaku overconfidence sebagai kecenderungan mengambil keputusan tanpa disadari, yang memberi bobot penilaian berlebih pada pengetahuan dan akurasi informasi yang dimiliki dengan mengabaikan informasi publik yang tersedia (Barber \& Odean, 2001). Pemodal cenderung menggunakan confidence intervals yang sempit ketika memrediksi suatu investasi. Pemodal menunjukkan keyakinan yang berlebih atas judgments mereka sendiri (yang belum tentu benar). Hasil penelitian perilaku overconfidence memberi 
pemahaman baru dalam riset keuangan, di mana aspek psikologi dianalisis lebih mendalam pada proses pengambilan keputusan investasi berisiko.

Barber \& Odean (2001) serta Pompian (2011) mengatakan bahwa implikasi dalam teori investasi menunjukkan perilaku overconfidence memicu bias pengambilan keputusan investasi. Bias tersebut dapat terjadi melalui: (1) kesalahan mengestimasi perusahaan sebagai target investasi yang berpotensi, (2) melakukan excessive trading karena percaya bahwa mereka memiliki pengetahuan yang tidak dimiliki pemodal lain, (3) pemodal tidak tahu, tidak mengerti, dan tidak menganalisis data statistik mengenai kinerja suatu investasi sehingga cenderung underestimate terhadap risiko (memungkinkan pemodal menderita kerugian akibat kinerja portofolio yang rendah), dan (4) pemodal cenderung mengambil underdiversified portfolios, yang sama halnya dengan mengambil risiko yang lebih tinggi. Mereka cenderung tidak mau mengubah risk tolerance walaupun tahu bahwa investasi tersebut berisiko.

Penelitian Pradikasari \& Isbanah (2018) dan Kartini \& Nugraha (2015) dalam konteks Indonesia menunjukkan bahwa perilaku overconfidence berpengaruh positif dan signifikan terhadap keputusan investasi. Perilaku overconfidence berpotensi membuat individu mengalami bias psikologi karena proses pengambilan keputusan tidak didasarkan pada expected utility tertinggi. Uraian tersebut memperkuat perumusan hipotesis ke dua dalam penelitian ini.

$\mathrm{H}_{2}$ : Overconfidence berpengaruh positif terhadap pengambilan keputusan investasi berisiko.

\subsection{Disposition Effect dan Keputusan Investasi}

Konsep disposition effect banyak didasari oleh teori loss aversion. Menurut Rau (2014), terdapat kecenderungan para pemodal untuk menjual lebih cepat saham-saham yang berkinerja baik (winner) dan menahan terlalu lama saham-saham yang berkinerja buruk (losser). Fenomena ini pada prinsipnya akan merugikan pemodal akibat saham winner yang dijual terus berkinerja, sementara saham losser yang ditahan malah semakin memburuk kinerjanya. Kondisi ini sering dialami pemodal di bursa saham.

Disposition effect sendiri merupakan anomali dalam keuangan keperilakuan karena terkait dengan kecenderungan pemodal untuk menjual lebih cepat saham berkinerja baik, dan menahan lebih lama saham berkinerja buruk. Investor mempertahankan saham ketika harganya turun, tetapi segera menjualnya ketika harga baru mulai naik (Rau, 2014). Summers \& Duxbury (2012) menyatakan bahwa faktor emosi berpengaruh pada disposition effect, seperti emosi penyesalan. Uraian di atas memperkuat rumusan hipotesis ke tiga dalam penelitian ini.

$\mathrm{H}_{3}$ : Disposition effect berpengaruh positif terhadap pengambilan keputusan investasi berisiko.

\subsection{Conservatism dan Keputusan Investasi}

Conservatism merupakan suatu proses mental yang terjadi pada individu, di mana individu lebih memercayai prediksi sebelumnya (prior views) dibandingkan informasi saat ini (Pompian, 2011). Di samping itu, terdapat tendensi individu merasa lebih terbebani untuk mengakui informasi baru yang sedang berkembang namun bertentangan dengan prediksinya. Hal ini dapat terjadi apabila apa yang diprediksi (diharapkan terjadi) oleh individu bertentangan dengan kondisi nyata yang sedang dialami.

Sebagai contoh, seorang pemodal menerima informasi buruk mengenai perusahaan yang sahamnya sudah dibeli. Berita baru ini kontradiktif dengan prediksi bulan lalu mengenai kinerja 
perusahaan tersebut. Pemodal yang mengalami conservatism cenderung akan kurang bereaksi (underreact) terhadap informasi baru ini karena lebih berpegang pada hasil prediksi bulan lalu. Kondisi ini mendorongnya untuk tidak bertindak atas berita baru tersebut, yang membuatnya mengalami bias psikologi. Bias kognitif ini dapat menyebabkan pemodal menjadi tidak fleksibel dalam merespon informasi baru, memberikan respon yang sangat lambat dan sulit untuk memroses informasi baru. Dengan demikian, bias concervatism akan memengaruhi individu dalam mengambil keputusan investasi.

$\mathrm{H}_{4}$ : Concervatism berpengaruh positif terhadap pengambilan keputusan investasi berisiko.

\subsection{Availability dan Keputusan Investasi}

Availability dalam psikologi merupakan rule of thumb yang memungkinkan individu untuk mengestimasi probabilitas suatu outcome berdasar pada seberapa umum dan dekat outcome tersebut terjadi (Santa-Clara \& Valkanov, 2003). Individu akan mengalami bias tersebut ketika cenderung memersepsikan probabilitas-probabilitas yang lebih mudah diingat dibandingkan prospek-prospek yang sulit dipahami. Sebagai ilustrasi, masyarakat di Amerika cenderung lebih mudah mengingat korban serangan ikan hiu dibandingkan korban pesawat jatuh karena frekuensi serangan hiu lebih tinggi di sana. Bias availability akan terjadi ketika individu lebih mudah terpengaruh pada informasi yang tersedia (available) dibandingkan pada informasi yang lengkap, objektif, dan faktual. Menurut Pompian (2011), setidaknya terdapat empat jenis bias availability yang sering dialami pemodal, yaitu: retrievability, categorization, narrow range of experience, dan resonance.

Retrievability dapat memengaruhi pengambilan keputusan pemodal, misalnya ketika ditanya perusahaan reksadana mana yang paling baik, maka akan lebih banyak responden yang memilih perusahaan yang lebih gencar mengiklankan produknya di media. Dari sisi investasi, pemodal akan memilih investasi yang informasinya tersedia (iklan, saran penasihat keuangan, atau rekomendasi teman).

Bias lain adalah categorization. Ketika individu ditanya negara mana di dunia ini yang memiliki prospek investasi terbaik, maka secara umum individu akan menjawab Amerika karena sudah terkategori dalam ingatan. Namun, Jika ditelusuri menggunakan informasi yang lengkap, objektif dan faktual, maka jawaban tersebut kurang tepat karena statistik menunjukkan bahwa lebih dari 50 persen kapitalisasi pasar modal berada di luar Amerika. Dari sisi investasi, pemodal cenderung akan memilih investasi berdasar pada daftar kategori perusahaan yang ada di memori dan yang mudah diingat (recall).

Di sisi lain, ketika karyawan pada industri teknologi yang dalam kesehariannya hanya berhubungan dengan rekan-rekan pada berbagai perusahaan high-tech ditanya: "industri mana yang menghasilkan tingkat investasi paling tinggi?" maka probabilitas untuk menjawab industri high-tech relatif akan lebih besar. Apabila terjadi demikian, maka individu tersebut dikatakan mengalami narrow range of experience. Hal ini juga terjadi pada pemodal yang cenderung memilih jenis investasi yang sesuai dengan pengalaman hidup, seperti saham perusahaan pada industri yang sama dengan bidang kerjanya atau yang beroperasi di wilayah tempat tinggalnya.

Dari sisi bias resonance, individu umumnya lebih menyukai jenis investasi yang dipersepsikan sesuai dengan personalitinya. Seorang individu yang hemat akan lebih menonjolkan aspek diskon dan tawar-menawar dibandingkan aspek lain dalam tokonya. Demikian juga pada 
pemodal yang cenderung memilih investasi yang dipersepsikan sesuai dengan personalitinya, atau jenis investasi yang berhubungan dengan perilakunya. Sebagai contoh, pemodal yang hemat cenderung menghindari saham yang mahal walaupun berkinerja baik. Penelitian Elmadiani (2020) menunjukkan bahwa bias availability berpengaruh positif dan signifikan terhadap pengambilan keputusan investasi pemodal saham di kota Batam. Penjelasan-penjelasan pada subbagian ini memperkuat argumentasi penulis dalam mengajukan hipotesis ke lima.

$\mathrm{H}_{5}$ : Availability berpengaruh positif terhadap pengambilan keputusan investasi berisiko.

\subsection{Efek Interaksi Literasi Keuangan}

Hayat \& Anwar (2016) serta Khalid et al. (2018) menyatakan bahwa pemodal dengan literasi keuangan baik cenderung menggunakan informasi keuangan yang dipublikasi dalam membuat keputusan investasi, sementara yang literasi keuangannya rendah cenderung mengambil keputusan berdasar saran keluarga, teman, dan para pialang saham. Merujuk pada konsep keperilakuan keuangan, bias-bias psikologi berupa perilaku herding, overconfidence, disposition effect, conservatism, dan availability cenderung dialami oleh pemodal.

Sementara itu, dari penjelasan literasi keuangan pada bagian sebelumnya, diketahui bahwa agen ekonomi yang memiliki literasi keuangan tinggi cenderung lebih mampu membuat keputusan yang lebih rasional. Budiarto \& Susanti (2017) menemukan bahwa literasi keuangan yang memadai mampu membuat pemodal mengambil keputusan investasi yang lebih tepat dan sesuai harapan. Hal ini ditegaskan kembali oleh Pradhana (2018) yang menjelaskan bahwa semakin tinggi tingkat pengetahuan seseorang, semakin bijak keputusan yang dibuat.

Uraian di atas secara teoritis memperkuat dugaan bahwa literasi keuangan yang baik berpotensi mendukung pemodal dalam memformulasi keputusan investasi yang lebih rasional. Hal ini mengindikasi bahwa bias-bias psikologi dalam pengambilan keputusan investasi relatif lebih rendah dialami para agen ekonomi yang memiliki tingkat literasi keuangan yang baik, demikian juga sebaliknya. Oleh karena itu, literasi keuangan dihipotesiskan mampu mereduksi pengaruh perilaku herding, overconfidence, disposition effect, conservatism, dan availability terhadap pengambilan keputusan investasi berisiko.

$\mathrm{H}_{6 a}$ : Literasi keuangan mereduksi pengaruh perilaku herding terhadap pengambilan keputusan investasi berisiko.

$\mathrm{H}_{6 \mathrm{~b}}$ : Literasi keuangan mereduksi pengaruh perilaku overconvidence terhadap pengambilan keputusan investasi berisiko.

$\mathrm{H}_{6 c}$ : Literasi keuangan mereduksi pengaruh disposition effect terhadap pengambilan keputusan investasi berisiko.

$\mathrm{H}_{6 \mathrm{~d}}$ : Literasi keuangan mereduksi pengaruh perilaku conservatism terhadap pengambilan keputusan investasi berisiko.

$\mathrm{H}_{6 \mathrm{e}}$ : Literasi keuangan mereduksi pengaruh perilaku availability terhadap pengambilan keputusan investasi berisiko.

\section{METODE PENELITIAN}

Riset ini merupakan penelitian kuantitatif berbasis survei dengan mengumpulkan informasi melalui kuesioner yang disebar kepada para pelaku keuangan. Terdapat empat jenis informasi yang dielaborasi dalam kuesioner, yaitu informasi mengenai faktor penyebab (herding, overconfidence, disposition effect, conservatism, dan availability), faktor yang dipengaruhi 
(keputusan investasi), faktor interaksi (literasi keuangan), dan faktor pengendali (jenis kelamin dan status pernikahan). Keempat informasi tersebut disusun dalam kuesioner penelitian untuk selanjutnya disebarkan kepada para responden yang memenuhi kriteria penyampelan.

Pengukuran dilakukan dengan skala likert di mana responden diminta untuk melakukan perangkingan terhadap preferensi pilihannya dengan cara memberi centang pada nilai skala likert yang ada. Penggunaan skala likert diharapkan dapat mempermudah dan mempercepat responden dalam menjawab pertanyaan (mengurangi efek kebosanan). Penelitian ini menggunakan skala likert 6 tingkat (penilaian) yang masing-masing mengandung pilihan jawaban pada rentang terendah (sangat tidak setuju) untuk skala satu (1) dan rentang tertinggi (sangat setuju) untuk skala enam (6). Penyampelan dalam riset ini menggunakan purposive sampling dengan menetapkan sejumlah kriteria, di mana responden minimal telah berusia 18 tahun, memiliki penghasilan sendiri, pernah melakukan investasi baik di pasar uang, pasar modal, dan atau pasar berjangka.

Riset ini mengembangkan empat model penelitian yang masing-masing dijabarkan dalam empat persamaan ekonometrika. Masing-masing model persamaan menunjukkan hubungan antar variabel dan pengukurannya, yang disajikan secara sitematis pada bagian berikut:

$$
\begin{aligned}
& K E P=\alpha+\beta_{1} \cdot L I K+\varepsilon \\
& K E P=\alpha+\beta_{2 .} H E R+\beta_{3 .} O V R+\beta_{4 .} D I S+\beta_{5 .} C O N+\beta_{6} \cdot A V T+\varepsilon \ldots \ldots \ldots \ldots \ldots . . . \text { Model (2) } \\
& K E P=\alpha+\beta_{7 . L I K}+\beta_{8 .} \cdot H E R+\beta_{9 .} \text { OVR }+\beta_{10 .} . D I S+\beta_{11} . C O N+\beta_{12 . A V T}+ \\
& \beta_{13 .} \text { HER }^{*} L I K+\beta_{14 .} \text { OVR }{ }^{*} L I K+\beta_{15 . D I S}{ }^{*} L I K+\beta_{16 .} \text { CON }^{*} L I K+
\end{aligned}
$$

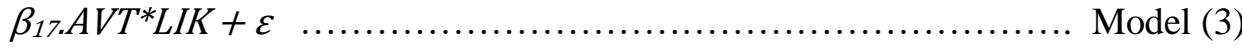

$$
\begin{aligned}
& \text { KEP }=\alpha+\beta_{18 .} \text { SEX }+\beta_{19 . M R D}+\beta_{20 . L I K}+\beta_{21} . H E R+\beta_{22 .} . \mathrm{VVR}+\beta_{23 .} . \mathrm{DIS}+ \\
& \beta_{24 .} \text { CON }+\beta_{25 . A V T}+\beta_{26} . H E R^{*} L I K+\beta_{27 .} \text { OVR }{ }^{*} \text { LIK }+ \\
& \beta_{28 .} D I S^{*} L I K+\beta_{29 .} C{ }^{*}{ }^{*} L I K+\beta_{30} . A V T^{*} L I K+\varepsilon
\end{aligned}
$$

Keterangan:

$K E P \quad=$ keputusan investasi,

$L I K \quad=$ literasi keuangan,

$H E R$ = perilaku herding,

OVR = perilaku overconvidence,

DIS = disposition effect,

CON = conservatism,

AVT = availability,

$S E X \quad=$ jenis kelamin,

$M R D=$ status pernikahan,

$\varepsilon \quad=$ Residual.

Pengujian model-model tersebut dilakukan dengan survei kuesioner. Indikator-indikator pertanyaan yang ditanyakan pada masing-masing variabel disajikan dalam tabel berikut: 
Tabel 1. Definisi Operasional dan Indikator

\begin{tabular}{|c|c|c|c|}
\hline No & Variabel & Definisi Operasional & Indikator \\
\hline 1 & $\begin{array}{l}\text { Keputusan } \\
\text { Investasi }\end{array}$ & $\begin{array}{l}\text { Keputusan dalam melakukan } \\
\text { transaksi jual-beli saham serta } \\
\text { analisis imbal hasil investasi yang } \\
\text { diperoleh, apakah sesuai dengan } \\
\text { yang diharapkan atau tidak. }\end{array}$ & $\begin{array}{l}\text { Frekuensi transaksi, melakukan } \\
\text { kombinasi sektor usaha, melakukan } \\
\text { analisis teknikal dan fundamental, } \\
\text { kepuasan terhadap hasil investasi dan } \\
\text { tingkat return yang diperoleh. }\end{array}$ \\
\hline 2 & $\begin{array}{l}\text { Literasi } \\
\text { Keuangan }\end{array}$ & $\begin{array}{l}\text { Pemahaman terhadap berbagai } \\
\text { instrumen investasi dan cara } \\
\text { analisisnya, termasuk pemahaman } \\
\text { terhadap lembaga keuangan. }\end{array}$ & $\begin{array}{l}\text { Memahami manfaat diversifikasi dan } \\
\text { istilah-istilah dalam perdagangan } \\
\text { saham, memahami hubungan risk dan } \\
\text { return, instrumen-instrumen investasi } \\
\text { dan lembaga-lembaga keuangan. }\end{array}$ \\
\hline 3 & Perilaku Herding & $\begin{array}{l}\text { Kecenderungan perilaku pemodal } \\
\text { untuk mengikuti pihak lain ketika } \\
\text { mengambil keputusan investasi. }\end{array}$ & $\begin{array}{l}\text { Herding transaksi (jual/beli), herding } \\
\text { produk investasi, herding kuantitas } \\
\text { transaksi, herding pengalaman, dan } \\
\text { herding perubahan keputusan } \\
\text { investasi. }\end{array}$ \\
\hline 4 & $\begin{array}{l}\text { Perilaku } \\
\text { Overconvidence }\end{array}$ & $\begin{array}{l}\text { Kecenderungan perilaku pemodal } \\
\text { yang meyakini kemampuan diri } \\
\text { sendiri dalam setiap pengambilan } \\
\text { keputusan investasi. }\end{array}$ & $\begin{array}{l}\text { Keyakinan pada kemampuan } \\
\text { berinvestasi, memilih jenis investasi, } \\
\text { mendapatkan return yang lebih tinggi, } \\
\text { hasil prediksi dan analisis sendiri, } \\
\text { memilih saham-saham yang } \\
\text { menguntungkan. }\end{array}$ \\
\hline 5 & $\begin{array}{l}\text { Disposition } \\
\text { Effect }\end{array}$ & $\begin{array}{l}\text { Kecenderungan perilaku pemodal } \\
\text { yang lebih cepat menjual saham } \\
\text { berkinerja dan menahan lebih lama } \\
\text { saham yang tidak berkinerja. }\end{array}$ & $\begin{array}{l}\text { Kebiasaan untuk segera } \\
\text { merealisasikan keuntungan pada saat } \\
\text { harga naik dan menahan penjualan } \\
\text { saham pada saat harga sedang turun. }\end{array}$ \\
\hline 6 & Conservatism & $\begin{array}{l}\text { Kecenderungan perilaku pemodal } \\
\text { yang lebih meyakini informasi dan } \\
\text { analisis masa lalu dibandingkan } \\
\text { informasi saat ini yang menunjukkan } \\
\text { hasil berbeda. }\end{array}$ & $\begin{array}{l}\text { Keyakinan pada analisis dan prediksi } \\
\text { sebelumnya, mengabaikan bad news } \\
\text { saat ini, informasi baru tidak selalu } \\
\text { benar, mengabaikan rekomendasi } \\
\text { analisis yang berbeda dengan prediksi } \\
\text { sebelumnya. }\end{array}$ \\
\hline 7 & Availability & $\begin{array}{l}\text { Kecenderungan perilaku pemodal } \\
\text { untuk memilih saham-saham yang } \\
\text { lebih dikenal, baik sektor usaha } \\
\text { maupun asal negara, termasuk saham } \\
\text { yang harganya sesuai dengan } \\
\text { perilaku keuangannya. }\end{array}$ & $\begin{array}{l}\text { Lebih menyukai saham yang dikenal, } \\
\text { yang berasal dari negara besar dengan } \\
\text { fundamental ekonomi yang kuat, yang } \\
\text { sektor usahanya sering didengar, dan } \\
\text { harga sahamnya sesuai. }\end{array}$ \\
\hline 8 & Jenis Kelamin & Data jenis kelamin responden. & Jenis kelamin (laki-laki/perempuan) \\
\hline 9 & $\begin{array}{l}\text { Status } \\
\text { Pernikahan }\end{array}$ & Data status pernikahan responden. & $\begin{array}{l}\text { Status pernikahan (menikah/belum } \\
\text { menikah) }\end{array}$ \\
\hline
\end{tabular}

Sumber: Hasil Konseptualisasi (2020)

Analisis data menggunakan bantuan piranti lunak SPSS dan EViews. Tahap analisis dimulai dengan pengujian statistik deskriptif serta validitas dan reliabilitas untuk menganalisis apakah instrumen yang digunakan memenuhi persyaratan pengumpulan data observasi. Pengujian kelaikan dan kesesuaian model (goodness of fit model test) dilakukan dengan menganalisis hasil uji F dan koefisien determinasi model. Sementara itu, analisis regresi dilakukan melalui dua tahap. Pertama, menganalisis hasil pengujian determinan keputusan investasi. Kedua, menganalisis hasil pengujian efek interaksi literasi keuangan dalam menjelaskan variabel keputusan investasi. Interpretasi hasil dilakukan setelah pengujian selesai dilakukan. 


\section{HASIL DAN PEMBAHASAN}

Penelitian ini mengambil setting pemodal di pasar modal Indonesia (Bursa Efek Indonesia, BEI). BEI sebagai salah satu representasi dari pasar modal berkembang memiliki keunikan tersendiri, terutama dari sisi indeks pasar (Indeks Harga Saham Gabungan, IHSG) yang terus bertumbuh dengan komposisi investor domestik yang semakin meningkat. Responden dalam riset ini merupakan investor domestik yang diakses secara personal oleh peneliti melalui jejaring di perusahaan-perusahaan sekuritas dan Kelompok Studi Pasar Modal (KSPM) di beberapa Universitas/Sekolah Tinggi Ilmu Ekonomi di Indonesia. Total responden berjumlah 125 pemodal yang dipilih secara acak dengan kombinasi karakteristik sebagaiamana tercantum dalam tabel profil responden berikut ini.

\begin{tabular}{|c|c|c|c|}
\hline $\begin{array}{l}\text { Profil Ringkas } \\
\text { Responden }\end{array}$ & Keterangan & $\begin{array}{l}\text { Nilai Absolut } \\
\text { (Orang) }\end{array}$ & $\begin{array}{l}\text { Nilai Relatif } \\
\text { (Persentase) }\end{array}$ \\
\hline \multirow{2}{*}{ Jenis Kelamin } & Laki-Laki & 46 & 37 \\
\hline & Perempuan & 79 & 63 \\
\hline \multirow{2}{*}{ Status Pernikahan } & Menikah & 20 & 16 \\
\hline & Belum Menikah & 105 & 84 \\
\hline \multirow{2}{*}{ Usia } & di bawah 25 tahun & 90 & 72 \\
\hline & 25 tahun atau lebih & 35 & 28 \\
\hline \multirow{2}{*}{ Pendidikan Terakhir } & Diploma/Sarjana & 61 & 49 \\
\hline & SMA atau ke bawah & 64 & 51 \\
\hline \multirow{2}{*}{ Pengalaman Investasi } & di bawah 5 tahun & 106 & 85 \\
\hline & 5 tahun atau lebih & 19 & 15 \\
\hline
\end{tabular}

Profil responden pada Tabel 2 menunjukkan bahwa sebagai besar responden berjenis kelamin perempuan (63\%) dengan dominasi belum menikah (84\%). Sementara dari sisi usia, tampak bahwa responden dalam riset ini merupakan investor pemula yang sebagian besar berumur di bawah 25 tahun (72\%). Dari sisi pendidikan responden, hasil olah data menunjukkan perimbangan yang cukup merata antara responden dengan tingkat pendidikan Diploma/Sarjana dengan responden yang tingkat pendidikannya SD-SMA, yaitu sebesar 49\% dan 51\%. Profil ini konsisten dengan durasi pengalaman investasi para responden di pasar modal, yang secara rerata $(85 \%)$ menunjukkan pengalaman investasi di bawah 5 tahun.

Berdasar hasil olahan ini dapat disimpulkan bahwa responden dalam penelitian ini merupakan investor pemula yang secara umum memiliki tingkat pendidikan yang cukup baik. Pendidikan yang cukup memadai diharapkan mampu memberikan hasil yang lebih baik karena riset ini melibatkan variabel moderasi berupa literasi (kemelekan) keuangan. Dengan demikian, responden yang diperoleh mendukung tujuan riset ini dalam mengobservasi efek interaksi literasi keuangan dalam pengambilan keputusan investasi berisiko.

Subbagian ini membahas beberapa pengujian dasar yang menjadi prasyarat baku dalam sebuah penelitian empiris berbasis survei kuesioner. Hasil uji reliabilitas menunjukkan bahwa indikator-indikator pertanyaan yang diuji memiliki nilai yang sangat baik, dengan angka cronbach's alpha 0,979. Hasil yang sama juga ditunjukkan pada pengujian validitas untuk indikator-indikator dalam kuesioner dengan rerata nilai korelasi di atas 0.6. Kedua hasil pengujian ini menunjukkan bahwa instrumen yang digunakan memiliki kehandalan dan konsistensi yang tinggi untuk digunakan dalam penelitian ini. 
Pengujian selanjutnya dilakukan untuk memastikan tidak terjadi pelanggaran pada asumsi dasar, seperti linieritas, normalitas, multikolinieritas, autokorelasi, dan heteroskedastisitas. Mengacu pada konsep central limit theorem, jumlah observasi sebanyak 125 responden dalam riset ini diasumsikan telah memenuhi normalitas residual. Pengujian linieritas menggunakan Ramsey reset test, sementara pengujian autokorelasi menggunakan Breusch-Godfrey serial correlation LM test. Untuk pengujian heteroskedastisitas, riset ini menggunakan Breusch-Pagan-Godfrey heteroscedasticity test, sementara pengujian multikolinearitas menggunakan collinnearity test di SPSS. Setelah memastikan seluruh hasil pengujian memenuhi asumsi dasar, maka dilanjutkan dengan tahap pengujian berikutnya. Tabel 3 menyajikan hasil olah data statistik deskriptif untuk seluruh variabel dalam model penelitian.

\begin{tabular}{lccccccc}
\multicolumn{7}{c}{ Tabel 3. Statistik Deskriptif } \\
\hline \multicolumn{1}{c}{ Keterangan } & CON & DIS & HER & KEP & LIK & OVR & AVT \\
Mean & 21,208 & 18,408 & 15,728 & 18,768 & 20,224 & 24,080 & 19,800 \\
Median & 21,000 & 15,000 & 14,000 & 15,000 & 19,000 & 25,000 & 20,000 \\
Maximum & 35,000 & 35,000 & 30,000 & 35,000 & 35,000 & 35,000 & 33,000 \\
Minimum & 10,000 & 7,0000 & 7,0000 & 7,0000 & 7,0000 & 10,000 & 9,0000 \\
Std. Dev. & 7,0348 & 7,0288 & 5,5290 & 7,1528 & 6,4892 & 6,6606 & 5,5518 \\
Skewness & 0,2013 & 0,9113 & 0,7608 & 0,6351 & 0,4226 & $-0,3344$ & 0,0982 \\
Kurtosis & 1,7257 & 2,6460 & 2,4740 & 2,1282 & 2,0698 & 2,0065 & 1,9850 \\
Observasi & 125 & 125 & 125 & 125 & 125 & 125 & 125 \\
\hline
\end{tabular}

Statistik deskriptif pada tabel di atas menunjukkan nilai rerata (mean) untuk masingmasing variabel (CON, DIS, HER, KEP, LIK, OVR, dan AVT) berada pada rentang 15,73 hingga 24,08 . Sebaran ini mengindikasi nilai variasi yang relatif baik, yang didukung oleh data deviasi standar yang stabil (berada pada kisaran 5,52 hingga 7,15) sehingga data observasi outlier tidak dijumpai. Kondisi tersebut mendukung tahap pengujian berikutnya, yang dibahas dalam sub-sub bagian berikut ini.

Tabel 4 menyajikan hasil pengujian untuk keempat model yang diuji dalam riset ini. Model-1 menguji pengaruh literasi keuangan terhadap keputusan investasi. Model-2 menguji pengaruh seluruh prediktor (HER, OVR, DIS, CON, dan AVT) terhadap keputusan investasi. Model-3 menguji efek interaksi literasi keuangan dengan seluruh variabel bebas, sementara model terakhir menguji dua variabel kontrol (jenis kelamin-SEX, dan status pernikahan-MRD) untuk melihat apakah terdapat perubahan pada efek interaksi literasi keuangan.

Literasi Keuangan (LIK) merupakan variabel moderasi yang dianalisis dalam riset ini. Literasi keuangan yang baik diharapkan dapat mengurangi bias-bias psikologi dalam pengambilan keputusan investasi berisiko. Pemahaman yang baik terhadap aspek keuangan dan instrumen investasi diharapkan mampu mendorong pengambilan keputusan investasi yang lebih rasional sehingga variabel ini diposisikan sebagai pemoderasi. Pemoderasi diharapkan memiliki pengaruh yang kuat terhadap variabel terikatnya (keputusan investasi-KEP).

Hasil pengujian Model-1 pada Tabel 4 di bawah menunjukkan LIK memiliki pengaruh positif dan signifikan terhadap KEP (signifikan pada aras satu persen). Hal ini mengindikasi bahwa literasi keuangan mampu menjadi prediktor yang baik dalam menjelaskan keputusan investasi pemodal. Temuan ini sekaligus memperkuat penempatan LIK sebagai pemoderasi dalam riset ini. Hasil ini konsisten dengan temuan Khalid et al. (2018) serta Hayat \& Anwar (2016). 
Tabel 4. Hasil Pengujian Model-Model Penelitian

\begin{tabular}{|c|c|c|c|c|c|}
\hline No & Variabel & Model-1 & Model-2 & Model-3 & Model-4 \\
\hline \multirow[t]{2}{*}{1} & Konstanta & 2,949 & $-1,620$ & 17,881 & 18,988 \\
\hline & $P$-value & $(0,050)^{* *}$ & $(0,566)$ & $(0,052) *$ & $(0,039) * *$ \\
\hline \multirow[t]{2}{*}{2} & LIK & 0,782 & - & $-0,305$ & $-0,202$ \\
\hline & $P$-value & $(0,000) * * *$ & - & $(0,479)$ & $(0,644)$ \\
\hline \multirow[t]{2}{*}{3} & HER & - & 0,475 & $-0,582$ & $-0,775$ \\
\hline & $P$-value & - & $(0,000) * * *$ & $(0,225)$ & $(0,115)$ \\
\hline \multirow[t]{2}{*}{4} & OVR & - & 0,210 & 0,053 & 0,143 \\
\hline & $P$-value & - & $(0,033) * *$ & $(0,861)$ & $(0,640)$ \\
\hline \multirow[t]{2}{*}{5} & DIS & - & 0,274 & 0,194 & 0,303 \\
\hline & $P$-value & - & $(0,012)^{* *}$ & $(0,683)$ & $(0,529)$ \\
\hline \multirow[t]{2}{*}{6} & $\mathrm{CON}$ & - & 0,197 & $-0,610$ & $-0,633$ \\
\hline & $P$-value & - & $(0,026) * *$ & $(0,046) * *$ & $(0,037)^{* *}$ \\
\hline \multirow[t]{2}{*}{7} & AVT & - & $-0,068$ & 0.376 & 0,379 \\
\hline & $P$-value & - & $(0,539)$ & $(0,241)$ & $(0,239)$ \\
\hline \multirow[t]{2}{*}{8} & HER*LIK & - & - & 0,039 & 0,045 \\
\hline & $P$-value & - & - & $(0,059) *$ & $(0,031) * *$ \\
\hline \multirow[t]{2}{*}{9} & OVR*LIK & - & - & $-0,002$ & $-0,006$ \\
\hline & $P$-value & - & - & $(0,903)$ & $(0,690)$ \\
\hline \multirow[t]{2}{*}{10} & DIS*LIK & - & - & $-0,003$ & $-0,008$ \\
\hline & $P$-value & - & - & $(0,872)$ & $(0,689)$ \\
\hline \multirow[t]{2}{*}{11} & CON*LIK & - & - & 0,037 & 0,039 \\
\hline & $P$-value & - & - & $(0,016) * *$ & $(0,011)^{* *}$ \\
\hline \multirow[t]{2}{*}{12} & AVT*LIK & - & - & $-0,027$ & $-0,029$ \\
\hline & $P$-value & - & - & $(0,082) *$ & $(0,061) *$ \\
\hline \multirow[t]{2}{*}{13} & SEX & - & - & - & $-0,723$ \\
\hline & $P$-value & - & - & - & $(0,425)$ \\
\hline \multirow[t]{5}{*}{14} & MRD & - & - & - & $-1,903$ \\
\hline & $P$-value & - & - & - & $(0,074)^{*}$ \\
\hline & $\mathrm{F}$ & 124,781 & 25,633 & 17,837 & 15,541 \\
\hline & $P$-value & $(0,000) * * *$ & $(0,000) * * *$ & $(0,000) * * *$ & $(0.000)^{* * *}$ \\
\hline & Adjusted $\mathrm{R}^{2}$ & 0,500 & 0,498 & 0,599 & 0,604 \\
\hline
\end{tabular}

Keterangan: Variabel Terikat $=$ KEP ; *** sig. $1 \% ; * *$ sig. $5 \% ; *$ sig. $10 \%$

Hasil pengujian Model-2 menunjukkan bahwa hanya variabel availability bias (AVT) yang tidak signifikan pengaruhnya terhadap keputusan investasi berisiko (KEP). Keempat prediktor lainnya, yaitu herding (HER), overconfidence (OVR), disposition effect (DIS), dan conservatism (CON) menunjukkan pengaruh positif pada aras signifikansi satu persen (HER) dan lima persen (OVR, DIS, dan CON). Hal ini menunjukkan bahwa prediktor-prediktor pada model regresi yang dibangun memiliki parsimoni yang baik dalam menjelaskan variabel keputusan investasi (KEP).

Model riset juga memiliki goodness of fit test yang sangat baik dengan tingkat signifikansi satu persen pada uji-F nya. Selain itu, dari sisi koefisien determinasi, hasil pengujian juga mendukung uji-F di mana nilai Adj- $\mathrm{R}^{2}$ berada pada kisaran 50 persen $(49,80 \%)$. Temuan ini sekaligus mengonfirmasi empat hipotesis pertama yang dikembangkan dalam penelitian ini, yaitu $\mathrm{H}_{1}$ (perilaku herding berpengaruh positif terhadap pengambilan keputusan investasi berisiko), $\mathrm{H}_{2}$ (overconfidence berpengaruh positif terhadap pengambilan keputusan investasi berisiko), $\mathrm{H}_{3}$ (disposition effect berpengaruh positif terhadap pengambilan keputusan investasi berisiko), $\mathrm{H}_{4}$ (concervatism berpengaruh positif terhadap pengambilan keputusan investasi berisiko). Sementara hipotesis ke lima (availability berpengaruh positif terhadap pengambilan keputusan investasi berisiko) tidak terdukung secara statistik. 
Model-3 menjelaskan hasil pengujian efek moderasi literasi keuangan (LIK). Literasi keuangan yang diposisikan sebagai pemoderasi dalam menjelaskan pengaruh variabel bebas (HER, OVR, DIS, CON, dan AVT) terhadap keputusan investasi berisiko (KEP). Pengujian kelaikan model melalui koefisien determinasi dan uji-F menunjukkan bahwa setelah melibatkan LIK, model riset tetap konsisten dengan hasil yang baik. Koefisien determinasi meningkat menjadi 60 persen (sebelumnya 49,8 persen), sementara hasil uji-F tetap menunjukkan dukungan terhadap model yang parsimoni dan laik (signifikan pada aras satu persen). Hasil ini sekaligus mengonfirmasi bahwa tingkat goodness of fit model test untuk model interaksi sangat baik.

Hasil uji efek moderasi menunjukkan dukungan terhadap LIK sebagai pemoderasi. Temuan ini mendukung penelitian Pradhana (2018), Khalid et al. (2018), serta Budiarto \& Susanti (2017). Pengujian pada Model-3 tersebut melibatkan variabel-variabel prediktor yang diinteraksikan dengan LIK. Hasil interaksi mengindikasi bahwa LIK memperlemah pengaruh perilaku herding terhadap keputusan investasi (KEP) (tingkat signifikansi turun dari satu persen menjadi sepuluh persen). Sementara pada variabel bias konfirmasi (CON), LIK juga memberikan efek interaksi dengan derajat signifikansi lima persen. Hasil ini tampak sama dengan pengaruh CON terhadap KEP sebelum diinteraksikan dengan LIK, yaitu signifikan pada aras lima persen. Sementara itu, pada pengujian variabel AVT tampak bahwa LIK mengubah arah pengaruh dari positif (sebelum diinteraksikan) menjadi negatif (setelah diinteraksikan) pada aras sepuluh persen. Hal ini juga mengindikasi bahwa LIK mereduksi pengaruh bias AVT terhadap KEP.

Interaksi LIK dengan variabel OVR dan DIS menunjukkan hal yang berbeda. OVR yang tadinya berpengaruh positif signifikan tampak menjadi tidak signifikan setelah diinteraksikan dengan LIK dengan arah pengaruh menjadi negatif. Hal yang sama juga terjadi pada variabel DIS yang sebelum diinteraksikan dengan LIK juga berpengaruh posistif signifikan terhadp LIK. Variabel ini menjadi tidak signifikan setelah diinteraksikan dengan LIK dan arah pengaruhnya menjadi negatif. Temuan-temuan ini memberi dukungan yang kuat terhadap dugaan bahwa literasi keuangan yang baik mampu mereduksi bias psikologi pemodal dalam pengambilan keputusan investasi berisiko. Pengujian pada Model-4 menambahkan dua variabel kontrol, yaitu jenis kelamin (SEX) dan status pernikahan (MRD). Hasil pengujian menunjukkan bahwa baik sebelum dikontrol maupun sesudah dikontrol dengan SEX dan MRD, LIK tetap memiliki efek interaksi yang konsisten dalam meredukasi bias-bias psikologi. Status pernikahan (MRD) yang menunjukkan pengaruh positif mengindikasi bahwa bias psikologi berpotensi dialami berbeda antara responden yang belum dan sudah menikah.

Temuan-temuan dalam riset ini menunjukkan dukungan yang kuat terhadap peran literasi keuangan sebagai pemoderasi dalam mengurangi bias psikologi pengambilan keputusan investasi. Literasi keuangan yang mengindikasi agen ekonomi memiliki pengetahuan dan kemelekan terhadap aspek investasi dan keuangan mampu mereduksi bias-bias psikologi yang dialami pemodal dalam pengambilan keputusan investasi berisiko. Bias-bias psikologi yang dianalisis dalam riset ini terdiri atas perilaku mengimitasi (herding), percaya diri berlebihan (overconfidence), efek disposisi (disposition effect), perilaku konservatif (concervatismn), dan perilaku availability. Perilaku herding menunjukkan kecenderungan pemodal untuk mengambil keputusan investasi yang didasarkan pada keputusan pemodal lain. Pada saat mengalami herding, pemodal cenderung mengabaikan informasi privatnya dan memilih mengambil keputusan yang sama dengan predisesornya. 
Sebelum diinteraksikan dengan literasi keuangan, perilaku herding tampak memiliki pengaruh yang sangat kuat terhadap keputusan investasi (signifikan pada aras satu persen). Hasil ini menjadi berbeda pada pengujian selanjutnya yang melibatkan intervensi literasi keuangan. Tampak pada pengujian efek interaksi literasi keuangan, pengaruh perilaku herding menjadi berkurang (melemah), yang ditunjukkan oleh angka signifikansi lima persen. Dengan demikian, secara empiris dapat dijelaskan bahwa literasi keuangan yang baik dapat mengurangi bias psikologi perilaku herding dalam pengambilan keputusan investasi.

Literasi keuangan juga tampak memiliki efek interaksi dengan faktor psikologi lainnya, yaitu rasa percaya diri yang berlebihan atau perilaku overconfidence. Pengambilan keputusan yang dipengaruhi oleh perilaku ini umumnya tidak disadari, di mana pemodal memberi bobot penilaian yang berlebihan terhadap akurasi informasi yang dimilikinya dan mengabaikan informasi relevan lainnya (Barber \& Odean, 2001; Qadri \& Shabbir, 2014). Hasil pengujian menunjukkan bahwa literasi keuangan memiliki efek interaksi dengan perilaku overconfidence dalam menjelaskan keputusan investasi.

Tingkat signifikansi sebesar lima persen menunjukkan literasi keuangan berperan sebagai pemoderasi dalam kajian ini. Temuan ini konsisten dengan penelitian Khalid et al. (2018) serta Hayat \& Anwar (2016), yang sekaligus mengonfirmasi bahwa perilaku overconfidence cukup dominan dialami pemodal ketika mengambil keputusan investasi. Argumen tersebut tampak pada hasil pengujian sebelum dan sesudah diintervensi dengan literasi keuangan. Secara statistik, kedua hasil pengujian tersebut memiliki derajat signifikansi yang setara, sebesar lima persen.

Telaah literatur pada bagian sebelumnya menunjukkan bahwa perilaku overconfidence berpotensi memicu bias psikologi dalam pengambilan keputusan investasi. Bias tersebut dapat mengakibatkan kesalahan mengestimasi sekuritas berkinerja sebagai target investasi serta berpotensi menyebabkan excessive trading karena terlalu meyakini bahwa mereka memiliki pengetahuan di atas rata-rata. Hal ini selanjutnya membuat para pemodal tidak menganalisis data kinerja suatu investasi dengan baik sehingga cenderung mengabaikan faktor risiko yang akan menyebabkan penurunan kinerja portofolio. Overconfidence mencerminkan perilaku pemodal yang irasional karena proses pengambilan keputusan tidak mengacu pada expected utility theory.

Efek interaksi literasi keuangan terhadap dua prediktor lainnya (disposition effect dan availability bias) juga menunjukkan hasil yang konsisten. Dugaan bahwa literasi keuangan akan menurunkan bias-bias psikologi yang dihadapi pemodal tampak pada hasil pengujian interaksi tersebut. Disposition effet yang sebelumnya positif signifikan sebelum diinteraksikan berubah menjadi tidak signifikan, bahkan arahnya menjadi negatif. Hal ini mengindikasi bahwa efek disposisi dapat diminimalisir apabila pemodal memiliki literasi keuangan yang baik. Efek ini terjadi karena pemodal memiliki kecenderungan untuk menjual saham winner (berkinerja baik) terlalu cepat dan menahan saham losser (berkinerja buruk) terlalu lama sehingga akan merugikan pemodal.

Perilaku ini sering dialami pemodal, misalnya saham yang baru naik segera dijual padahal fundamentalnya sangat bagus, sementara saham yang sudah turun harganya masih terus ditahan padahal fundamentalnya telah menunjukkan penurunan. Hal ini terjadi karena pemodal "takut" saham yang sudah naik akan turun lagi sehingga buru-buru dijual, demikian sebaliknya, pada saham yang harganya sudah turun, pemodal masih "percaya" penurunan tersebut hanya sementara 
dan akan naik kembali. Pada kondisi ini, pemodal sebenarnya mengalami bias psikologi dengan enggan merealisasikan kerugiannya dan tidak mau mengakui telah keliru memilih saham.

Pengujian selanjutnya menginteraksikan literasi keuangan dengan perilaku availability. Perilaku ini menjelaskan bahwa pemodal cenderung memersepsikan probabilitas-probabilitas yang lebih mudah diingat dibandingkan prospek-prospek yang sulit dibayangkan atau dipahami (Santa-Clara \& Valkanov, 2003). Hasil pengujian statistik sebelum diinteraksikan menunjukkan bahwa perilaku ini tidak terkonfirmasi memengaruhi keputusan investasi. Sementara itu, setelah diinteraksikan tampak bahwa literasi keuangan memperlemah pengaruh perilaku ini terhadap pengambilan keputusan investasi. Hasil statistik dengan koefisien regresi bertanda negatif pada aras signifikansi sepuluh persen mengindikasi bahwa literasi keuangan yang semakin baik akan menurunkan pengaruh availability bias terhadap pengambilan keputusan investasi berisiko.

Temuan selanjutnya membahas perilaku konservatisme (conservatism). Perilaku ini cenderung mendorong pemodal lebih memercayai prediksi mereka sebelumnya atau prior views dibandingkan informasi relevan saat ini (De Bondt \& Thaler, 1985). Hasil analisis menunjukkan bahwa literasi keuangan tidak begitu efektif dalam mereduksi perilaku ini. Dari hasil pengujian statistik, tampak bahwa sebelum dan sesudah diinteraksikan dengan literasi keuangan, perilaku konservatisme konsisten memengaruhi pengambilan keputusan investasi berisiko pada aras lima persen. Hasil ini sekaligus mengindikasi bahwa meskipun literasi keuangan pemodal telah baik, masih ada kecenderungan para pemodal mengalami bias ini ketika mengambil keputusan investasi berisiko. Sebagai diskusi akhir, bias kognitif ini berpotensi membuat pemodal menjadi tidak fleksibel dalam merespon informasi baru dan cenderung memberikan respon yang lambat terhadap informasi baru. Keenganan pemodal untuk mengakui informasi baru yang bertentangan dengan prediksi dan harapannya memperkuat temuan ini (Pompian, 2011).

\section{SIMPULAN DAN REKOMENDASI}

Riset ini menganalisis peran literasi keuangan dalam memoderasi pengaruh bias-bias psikologi terhadap pengambilan keputusan investasi berisiko. Hasil analisis menunjukkan bahwa literasi keuangan dapat menjadi pemoderasi yang secara umum mampu mereduksi bias-bias psikologi yang dialami para pemodal ketika mengambil keputusan investasi berisiko. Interaksi literasi keuangan dengan perilaku herding, overconfidence, disposition effect, dan conservatism menunjukkan pengaruh yang semakin lemah dan bahkan mampu mengubah arah pengaruh dari yang tadinya positif menjadi negatif (overconficende dan disposition effect).

Literasi keuangan mereduksi pengaruh perilaku herding dari aras signifikansi satu persen menjadi sepuluh persen. Sementara itu, interaksi dengan perilaku overconfidence dan disposition effect menunjukkan hasil yang lebih kentara, di mana dari yang tadinya siginfikan menjadi tidak signifikan di mana arah pengaruh juga berubah dari positif menjadi negatif. Temuan lain menunjukkan bahwa pada saat diinteraksikan dengan availability bias, literasi keuangan mampu memperlemah bias psikologi tersebut secara siginfikan. Sebelum diinteraksikan dengan literasi keuangan, perilaku ini tampak tidak siginifikan, sementara setelah diinteraksikan pengaruh perilaku ini terhadap pengambilan keputusan investasi menjadi negatif signifikan.

Temuan lain dari riset ini mengindikasi bahwa literasi keuangan tidak mampu mereduksi pengaruh perilaku konservatisme terhadap keputusan investasi. Hal ini tampak pada hasil pengujian yang tetap positif siginifikan, baik sebelum maupun setelah diinteraksikan dengan LIK 
(signifikan pada aras lima persen). Temuan ini menunjukkan bahwa meskipun pemodal memiliki literasi keuangan yang baik, namum pengaruh perilaku konservatisme masih terjadi ketika mereka mengambil keputusan investasi.

Riset ini menggunakan survei kuesioner dalam pengumpulan data observasi. Penelitian survei belum mampu membahas sisi perilaku secara komprehensif sehingga hasil kajian ini lebih mengarah pada pembahasan sisi persepsi responden. Selain itu, responden dalam riset ini yang lebih didominasi investor pemula dengan pengalaman investasi di bawah lima tahun juga menjadi keterbatasan tersendiri dalam melakukan generalisasi hasil riset.

Keterbatasan-keterbatasan tersebut menjadi catatan tersendiri bagi riset selanjutnya untuk topik kajian ini. Penelitian selanjutnya perlu mempertimbangkan desain eksperimen untuk mengungkap lebih jauh peran literasi keuangan sebagai pemoderasi. Penggunaan desain eksperimen diharapkan mampu mengelaborasi sisi perilaku yang belum mampu diungkap dengan baik dalam riset ini. Sementara dari sisi responden, karakteristik yang seimbang antara jenis kelamin dan status pernikahan perlu mendapat perhatian tersendiri. Hasil pengujian pada Model-4 mengonfirmasi hal tersebut dan sekaligus menunjukkan konsistensi literasi keuangan sebagai pemoderasi meskipun telah dikontrol dengan status pernikahan dan jenis kelamin.

Temuan-temuan dalam riset ini diharapkan mampu memberi warna baru dalam penelitian keperilakuan keuangan di Indonesia, khususnya dalam menganalisis bias-bias psikologi yang sering dialami pemodal ketika mengambil keputusan investasi berisiko. Bias-bias psikologi yang dialami pemodal berpotensi membuat hasil investasi menjadi kurang optimal sehingga perlu direduksi. Temuan-temuan dalam riset ini merekomendasikan pentingnya mempertimbangkan peran literasi keuangan dalam mereduksi bias-bias psikologi tersebut.

\section{DAFTAR PUSTAKA}

Addinpujoartanto, N. A., \& Darmawan, S. (2020). Pengaruh Overconfidence, Regret Aversion, Loss Aversion, dan Herding Bias terhadap Keputusan Investasi di Indonesia. Jurnal Riset Ekonomi dan Bisnis, 13(3), 175-187.

Al-Tamimi, H. A. H. (2009). Financial Literacy and Investment Decisions of UAE Investors. The Journal of Risk Finance.

Atkinson, A., \& Messy, F.-A. (2013). Promoting Financial Inclusion through Financial Education: OECD/INFE Evidence, Policies and Practice.

Bakar, S., \& Yi, A. (2016). The Impact of Psychological Factors on Investors' Decision Making in Malaysian Stock Market: A Case of Klang Valley and Pahang. Procedia Economics and Finance, 35, 319-328. https://doi.org/10.1016/S2212-5671(16)00040-X

Barber, B. M., \& Odean, T. (2001). Boys Will Be Boys: Gender, Overconfidence, and Common Stock Investment. The Quarterly Journal of Economics, 116(1), 261-292.

Budiarto, A., \& Susanti. (2017). Pengaruh Financial Literacy, Overconfidence, Regret Aversion Bias, dan Risk Tolerance terhadap Keputusan Investasi (Studi pada investor PT. Sucorinvest Central Gani Galeri Investasi BEI Universitas Negeri Surabaya). Jurnal Ilmu Manajemen (JIM), 5(2).

Cartwright, E. (2018). Behavioral economics (Third Edit). Routledge.

Chen, H., \& Volpe, R. P. (1998). An Analysis of Personal Financial Literacy Among College Students. Financial Services Review, 7(2), 107-128. 
De Bondt, W. F. M., \& Thaler, R. (1985). Does The Stock Market Overreact? The Journal of Finance, 40(3), 793-805.

Elmadiani, C. (2020). Pengaruh Emotional Contangion, Availaibity Bias, Overconfidence, Loss Aversion dan Herding Terhadap Pengambilan Keputusan Investasi Saham di Kota Batam. Disertasi. Universitas Internasional Batam.

Filip, A., Pochea, M., \& Pece, A. (2015). The Herding Behaviour of Investors in The CEE Stocks Markets. Procedia Economics and Finance, 32, 307-315.

Giesler, M., \& Veresiu, E. (2014). Creating The Responsible Consumer: Moralistic Governance Regimes and Consumer Subjectivity. Journal of Consumer Research, 41(3), 840-857.

Gill, S., Khurshid, M. K., Mahmood, S., \& Ali, A. (2018). Factors Effecting Investment Decision Making Behavior: The Mediating Role of Information Searches. European Online Journal of Natural and Social Sciences, 7(4), pp-758.

Hayat, A., \& Anwar, M. (2016). Impact of Behavioral Biases on Investment Decision; Moderating Role of Financial Literacy. https://ssrn.com/abstract $=2842502$ or http://dx.doi.org/10.2139/ssrn.2842502

Kartini, K., \& Nugraha, N. F. (2015). Pengaruh Illusions of Control, Overconfidence dan Emotion terhadap Pengambilan Keputusan Investasi pada Investor di Yogyakarta. Asian Journal of Innovation and Entrepreneurship, 4(2), 114-122.

Khairunizam, \& Isbanah, Y. (2019). Pengaruh Financial Literacy dan Behavioral Finance Factors terhadap Keputusan Investasi (Studi terhadap Investor saham Syariah pada Galeri Investasi Syariah UIN Sunan Ampel Surabaya). Jurnal Ilmu Manajemen (JIM), 7(2).

Khalid, R., Javed, M. U., \& Shahzad, K. (2018). Impact of Behavioral Biases on Investment Decision Making with Moderat-ing Role of Financial Literacy. Jinnah Business Review, 6(2), 34-41.

Lakshman, M. V, Basu, S., \& Vaidyanathan, R. (2013). Market-Wide Herding and The Impact of Institutional Investors in The Indian Capital Market. Journal of Emerging Market Finance, 12(2), 197-237.

Lusardi, A., \& Mitchell, O. S. (2013). The economic importance of financial literacy: Theory and evidence (Working Paper No. 18952). National Bureau of Economic Research.

Moradi, M., Mostafaei, Z., \& Meshki, M. (2013). A Study on Investors' Personality Characteristics and Behavioral Biases: Conservatism Bias and Availability Bias in The Tehran Stock Exchange. Management Science Letters, 3(4), 1191-1196.

OJK. (2016). Survei Nasional Literasi dan Inklusi Keuangan. Jakarta: Otoritas Jasa Keuangan.

Ouarda, M., El Bouri, A., \& Bernard, O. (2013). Herding Behavior Under Markets Condition: Empirical Evidence on The European Financial Markets. International Journal of Economics and Financial Issues, 3(1), 214.

Pompian, M. M. (2011). Behavioral finance and wealth management: How to Build Investment Strategies That Account for Investor Biases (Vol. 667). John Wiley \& Sons.

Pradhana, R. W. (2018). Pengaruh Financial Literacy, Cognitive Bias, dan Emotional Bias terhadap Keputusan Investasi (Studi pada Investor Galeri Investasi Universitas Negeri Surabaya). Jurnal Ilmu Manajemen (JIM), 6(3).

Pradikasari, E., \& Isbanah, Y. (2018). Pengaruh Financial Literacy, Illusion of Control, Overconfidence, Risk Tolerance, dan Risk Perception terhadap Keputusan Investasi pada Mahasiswa di Kota Surabaya. Jurnal Ilmu Manajemen (JIM), 6(4). 
Qadri, S. U., \& Shabbir, M. (2014). An Empirical Study of Overconfidence and Illusion of Control Biases, Impact on Investor's Decision Making: An Evidence from ISE. European Journal of Business and Management, 6(14), 38-44.

Rau, H. A. (2014). The Disposition Effect and Loss Aversion: Do Gender Differences Matter? Economics Letters, 123(1), 33-36.

Sachan, A., \& Chugan, P. K. (2020). Availability Bias of Urban and Rural Investors: Relationship Study of the Gujarat State of India. Journal of Behavioural Economics, Finance, Entrepreneurship, Accounting and Transport, 8(1), 1-6.

Santa-Clara, P., \& Valkanov, R. (2003). The Presidential Puzzle: Political Cycles and The Stock Market. The Journal of Finance, 58(5), 1841-1872.

Summers, B., \& Duxbury, D. (2012). Decision-Dependent Emotions and Behavioral Anomalies. Organizational Behavior and Human Decision Processes, 118(2), 226-238.

Tversky, A., \& Kahneman, D. (1992). Advances in Prospect Theory: Cumulative Representation of Uncertainty. Journal of Risk and Uncertainty. https://doi.org/10.1007/BF00122574

Yao, J., Ma, C., \& He, W. P. (2014). Investor Herding Behaviour of Chinese Stock Market. International Review of Economics \& Finance, 29, 12-29. 